\title{
Implementing E-Public Service in North Sumatera: Prospects and Challenges
}

\author{
Asima Yanty Siahaan \\ Department of Public Administration \\ University of Sumatera Utara \\ Medan, Indonesia \\ asimayantysiahaan@gmail.com
}

\author{
Tunggul Sihombing \\ Department of Public Administration \\ University of Sumatera Utara \\ Medan, Indonesia \\ Tunggul.toeng@gmail.com
}

\begin{abstract}
This article explores the implementation of e-public service in Binjai city in North Sumatra by focusing on both the contributions of integrating ICT in public service delivery and institutional challenges facing the government of Binjai city in improving the quality of public service delivery in Binjei city. It demonstrates the gap between the disposition of implementers and the provision of infrastructure, knowledge and capacity have significantly obstructed the achivement of local government in implementing various electronic based service delivery programs. It recommends that intensive dissemination of information on the goals and processes of e-Musrenbang to all segments of the community is urgently required.
\end{abstract}

Keywords-E-public service; Smart city; Electronic based development planning.

\section{INTRODUCTION}

Public service is a vein in improving the welfare of society and in ensuring the fulfillment of basic rights of citizens. Indonesia's Law No.25 Year 2009 on Public Service affirms the importance of delivering quality public services. The government's strategy to increase public services through the establishment of One Roof Service Unit (UPTSA) at the municipal or district government level is still not able to bring public service closer to the community given the high level of public discontent on accessibility, communication quality and public service management. The high level and vulnerability of corruption in Indonesia, although based on Transparency International (TI), the Corruption Perception Index (CPI) score of Indonesia increased in 2013 was 32 (ranked 114 out of 177 countries) and CPI score of 2014 to 34 (rank 109 of 175 state), is seen as one of the factors that result in low quality of public services in Indonesia (http://www.ti.or.id/index.php/news/2016/01/04/2015-kualitaspelayanan-publik-prestasi -still low).

Governance of electronic-based government (egovernment) is one form of development of this new technology. Bekkers and Hamburg (2005: 1) argue that egovernment is one of the proposed and suggested innovations in the discussion of the modernization of public administration. In line with this statement, the OECD (2003: 63) defines egovernment as the capacity to change public administration through the use of technology, information and computer (ICT) or is used to describe a new form of government built around ICT.

Thus, e-government is a capacity or power to change public administration through the use of information and communication telecommunications or is being used to describe a new form of government built on the use of information and communication telecommunications. In the early 1990s, various forms of service using e-government emerged in the service of citizens as well as the private sector. E-government is increasingly being used by developed and developing countries as a strategy to improve public services since the 1990s. Public services such as bill payments, information on government services, application forms, proof of identity and government documents are all provided through e-government facilities. In general, e-procurement aims to prevent the emergence of problems associated with delays in governance processes, uncertainty, lack of transparency and corruption practices (Beckers et.al 2005).

In improving the quality of public service delivery, the government of Indonesia since 1990s has been promoting the electronic governance (e-governance) in delivering services Electronic governance has been defined as an important part of bureaucratic reform in Indonesia. In Indonesia the implementation of e-government is strengthened by the issuance of Presidential Instruction No. 3 of 2003 on the National Development Policy of E-Government and Strategy. This policy is an effort to develop the administration of electronic based government in order to improve the quality of society from the service in an effective, efficient, transparent and competitive, fair and accountable. This is supported by the issuance of Law no. 25/2009 on Public Services, in particular, article 4 on the principles of public service delivery. The issuance of Law no. 11 of 2008 on Information and Electronic Transactions (ITE) and Law No. 14 on Public Information Openness also strengthens the role of ICT in public services. The innovative service system of e-government is also reaffirmed in the Indonesia Serving Movement program which is the implementation of the Presidential Instruction No. 12 of 2016 on the National Movement of the Mental Revolution.

Through Inpres no. 3 of 2003 on E-Government Development Strategy has several mandates including: developing a reliable and trustworthy and affordable service system by the wider community; structuring management, 
system and work process of central government and local government holistically; Utilization of information technology optimally; Increasing the role of business world and development of telecommunication and information technology industry; Development of human resources in government and improvement of community e-literacy; The implementation of systematic development through realistic and measurable stages. The main purpose of e-government implementation is to improve the quality of public services. The e-government system can promote transparent, accountable, corruption-free, slender bureaucracy, and increase citizen participation in governance control.

This paper focuses on both the contributions of integrating ICT in public service delivery and institutional challenges facing the government of Binjai city in improving the quality of public service delivery in Binjei city.

\section{RESEARCH METHOD}

The method used is descriptive research method with qualitative approach. This research consists of reviewing the literature and government policies related to electronic-based public services and field studies to examine the factors and implications of electronic-based public services in North Sumatra by focusing on Binjai City.

Field study using interview and observation techniques are aimed at assessing the implementation of e-public service policies, identifying problems faced by local governments in implementing e-public services.

\section{RESULTS AND DISCUSSIONS}

\section{A. Smart City (Binjai City)}

Soft Launching Binjai Smart City (BSC) was conducted in December 2016. At the time of service BSC was still limited to e-Planning and e- Musrenbang. In April 2017 the service was developed by launching other new electronic-based public service programs such as e-Doctor, e-Warung (electronic based grocery), e-Licensing, and e-Society. This development model is done by adopting e-Government system of Surabaya city. Smart City implemented in Binjai City focuses on the utilization of today's technology to improve service to the people of Binjai City. The objective of Binjai Smart City implementation is to solve the problems of Binjai City with the priority development program of Binjai City starting from infrastructure, government, community empowerment, and teknopolis to know the condition of land which is suitable for agriculture land or building land.

Midterm development planning of Binjai (RPJMD) 20162021 emphasizes the importance of improving e-governance in realizing good governance. This RPJMD demonstrates the disposition of the city government in implementing egovernment in realizing smart city. In order to realize the achievement of Vision and Mission of Binjai City Development in the next five years will be prioritized to 6 Development Priorities namely: 1. Improving Religious Life, Law Enforcement, Strengthening Good Governance, Public Service and Public Participation in Development in order to realize Smart Governance; 2. Improving the Quality and affordability of education services; improving the quality and accessibility of health services in order to realize smart, healthy, productive and prosperous human resources; improving infrastructure, regional development, and environmental conservation in order to realize smart mobility, smart living and smart environment; improving social economic and social welfare in order to realize the growth high economic and gap between communities and between regions (smart economy and smart prosperity).

\section{B. Binjai Smart City Center (BSCC): Coordination Strategy in Implementing E-Public Service}

To improve coordination among the various stakeholder institutions involved in the implementation of Binjai Smart City, the Binjai Smart City Center (BSCC) is established. $\mathrm{BSCC}$ is equipped with necessary infrastructure related to the e-government and experts on ICT technology and operators of the program. It is a system used by Binjai city government to integrate data and monitoring various public service programs and activities. In the implementation of this program, the Mayor of Binjai is in charge of the Smart City Binjai Program.

As coordinator coordinating Team from Binjai Smart City Center (BSCC) The mayor appoints a Commander member to report the progress of BSCC to the mayor of Binjai. Commander will interact much with the team leaders of the involved BSCC and OPD. BSCC itself is chaired by IT Team from Medan State Polytechnic as developer. Eventhough BSCC operates very recent in 2016, interviews with various stakeholders highlight the prospects and benefits of e-public service such as e-Doctor, e-Community and e-Licensing.

As part of the Local Government Organization (OPD), Bappeda is also a line of coordination and communication between the BSCC team and the Binjai City Regional Organization. BAPPEDA's role is very strategic in directing OPD to be actively involved in the implementation of Binjai Smart City program. Diskominfo Kota Binjai is more involved in technical aspect in cooperation with team from Politekhnik Negeri Medan in managing BSCC.

\section{Electronic-based Consultative Development Planning (E- Musrenbang) as A Means of Increasing Public Participation in Public Service Delivery}

E-Musrenbang is an application to increase community participation in development planning from head of environment to city government. Binjai Smart City Commander (BSCC) has launched e-Musrenbang application. Through e-Musrenbang citizens can see the compilation of development proposals and provide support to the proposed development. This application aims to facilitate the implementation of Musrenbang in collecting proposals from neighborhood head level to city level and improve the quality of Musrenbang implementation in terms of community participation.

Through E-Musrenbang citizens can be involved and better understand their city's development planning process and look at development proposal formulation and provide support for development proposals. To be able to access E-Musrenbang people must login by using the Username and NIK (Population 
Identity Number). Only after login will the general public and community leaders (community representatives) be able to participate actively in E-Musrenbang by giving suggestions and responses to the proposals given by other members of Binjai residents. This procedure is set to restrict people who are not residents of Binjai who wish to access E-Musrenbang. The presence of E-Musrenbang facilitates the implementation of musrembang in the collection of proposals - proposals from the level of the head of hamlets to city government. The benefits of e-Musrenbang include:

- The proposed development becomes more transparent.

- Simplify the implementation of Musrenbang not limited by time and place.

- The database of development proposals that can be accessed by the whole community.

- The chronology of the proposal is clear.

\section{Limited Infrastructure and Access to Participate in E- Musrenbang}

Binjei city government through RPJMD Binjei city has demonstrated the government's commitment in implementing e-public service in the city of Binjei. But the limitations of infrastructure make it difficult for the village government to implement e-musrembang urban village. Internet facilities and computer equipment at BSCC are not equipped with adequate urban infrastructure. In every urban village of Binjai there is only one computer facility but the wifi network is not yet available due to the unavailability of infrastructure procurement in E-Musrenbang. Meanwhile, in every urban village there are 2 officers and 6 chiefs of environment who are all involved in the operation of the process associated with EMusrenbang.

With only 1 unit of computer available while the EMusrenbang process requires the availability of a computer for every officer involved, they must alternate using the computer. Moreover, the fingerprint tool that has been available in the village office but can not be used because of the unavailability of wifi in the office of the kelurahan. This limited condition and inadequacy of the infrastructure resulted in the EMusrenbang process becoming more difficult and less effective. Based on interviews with the participants and operators of Musrenbang the impementation of e-Musrenbang tends to be rethorical because eventhough government has provided them with 1 computer however compared to their task and the public they serve, the computer is not enough. Therefore they have to use their personal computer and due to the inavailability of wifi, they frequetly cannot fulfill their obligated task., to still use the private network, and even then still the

The unavailability of wifi also resulted in E-Musrenbang can not be done routinely. E-Musrenbang is only done once since the policy on E-Musrenbang is set. The urban village's strategy to overcome the limitations of this computer is to use a laptop and personal modem. However, this strategy can not be undertaken by all urban villages in the city of Binjei, especially villages with people who have low economic conditions or are often referred to as 'poor villages'. In this village the implementation of musrembang is still done manually that is by conducting a village meeting with the head of environment consisting of 9 people who are in Pahlawan. Implementation of e-musrembang in this urban village although had been impelemented once in January but still in trial and experiment mode. In this e-musrenbang experiment, urban village officials still use their own personal laptops due to unavailability of the infrastructure.

Computers and wifi are very important infrastructures because inputting data is a very basic activity in the EMusrenbang process. The fingerprint facility that has been given to the kelurahan is withdrawn to the kecamatan because it can not be utilized due to the absence of wifi. Although theoretically, the implementation of E-Musrenbang which is part of e-government is expected to improve efficiency, transparency and public participation in governance but this can not be realized without considering the completeness of infrastructure and human resource capacity and adequate budget. This case shows that the lack of consideration of the overall infrastructure prior to implementing e-government would in fact lead to inefficiency in government administration.

The E-Musrenbang listed in the RPJMD should be supported by budget availability. There are interesting things, if in the district and village already provided Computer and Internet Devices as a supporting media for e-gov and Smart City. There is now a request from the Head of the Environment for them to be given an IPAD whose purpose is to facilitate access to Kepling in monitoring the implementation of eMusrenbang. However, it can not be given due to budgetary factors, but will be assessed if necessary will be incorporated into planning first in order to be budgeted.

\section{E. Limited Konwledge and Capacity in Implementing E- Public Service}

Institutionally, Bappeda Binjai city is the coordinator in the implementation of e-musrenbang aimed at the preparation of regional development plans. This e-government team has been awarded the Mayor's Decree confirming their position in the governance process of the city of Binjai. E-Musrenbang is implemented in Binjai city since 2016 and its implementation is done gradually. The change of the musrenbang process and planning from manual to digital (electronic-based) demands changes in the capacity and understanding of local government-related human resources and, moreover, to introduce electronic language to the community. The lack of understanding from officials at the head of the Department, Head of Field to the ranks of employees related to the use of IT is the most significant weakness of human resource in conducting smart city. There are also very few of the Binjai city government human resources who are interested in increasing their knowledge and capacity in the use of ICT in governance.

At the kelurahan level all urban village officials including the head of the environment are involved in implementing EMusrenbang. However, as described above, limited 
infrastructure constraints have hampered performance rather than human resources in implementing e-Musrenbang. Human Resource performance is also limited by the absence of SK of the city or kelurahan government regarding the status of the eMusrenbang operator.

To improve human resources in the implementation of eMusrenbang Local Government Organizations (OPD) associated with e-government and BSCC products as a whole have been involved in a team and have been trained. However, this training is still seen as only limited to the normative knowledge of BSCC products such as e doctors, e licensing (Interview, Interview, Saifan, Economic Sub-Bappeda of Binjai City, M. Iskandar, Kepling II Kelurahan Pahlawan Binjai 14 August 2017).

\section{CONCLUSIONS}

Implementation of E-Musrenbang which is part of egovernment is expected to improve the efficiency and public participation in governance but this can not be realized without considering the infrastructure and capacity of human resources and adequate budget. The limited human resources and budget in the implementation of electronic-based public services has resulted in limited local government performance in research locations to implement various programs related to the improvement of public services via the internet.

Although e-Musrenbang provides space for citizens' participation to address their needs and engage in development planning, in order for the e-Musrenbang to be understood and relevant to diverse needs and interests of communities, City government of Binjai needs to improve the content of the web to be more interactive. Due to the very limited access to infrastructure especially the unavailability of internet facility has obstructed the majority of community members to participate in e-Musrenbang. Also refering to limited knowledge and understanding on e-Musrenbang, it is urgent to disseminate information on the goals and processes of eMusrenbang to all segments of the community in order to avoid the ignorance to the realm of popular democratic goals of eMusrenbang.

\section{ACKNOWLEDGMENT}

We highly appreciate University of Sumatera Utara, Indonesia for providing funding which enabled us to publish this article.

\section{REFERENCES}

[1] Bekkers, Victor, dan Homburg, Vincent (eds.) (2005). E-Government as An Information Ecology: Backgrounds and Concepts. In "The Information Ecology of E-government:E-Government as Institutional and Technological Innovation in Public Administration". Press Netherlands: IOS

[2] Lindgren , Ida \& Gabriella Jansson. 2013. 'Electronic services in the public sector: A conceptual Framework' Government Information Quarterly, (30), 2, 163-172. http://dx.doi.org/10.1016/j.giq, accesed on 11 March 2017.

[3] Misuraca G C 2007'E-Governance in Africa: From Theory to Practice A Handbook on ICTs for Local Governance (Africa World Press: New Jersey, International Development Research Centre: Ottawa)

[4] Ndou V 2004 E-Government for Developing Countries: Opportunities and Challenges EJISDC. 18 (1), 124.

[5] OECD E-Government Task Force. (2003). The Case for E-Government: Excerpts from the OECD Report"The E-Government Imperative". OECD Journal on Budgeting - Vol. 3, No. 1.

[6] USAID. 2009. Innovations in Local Public Service Management Challenges and Opportunities in Decentralized Governance in Indonesia. pdf.usaid.gov/pdf_docs/PNADP067.pdf. Accessed on 5 March 2017. 